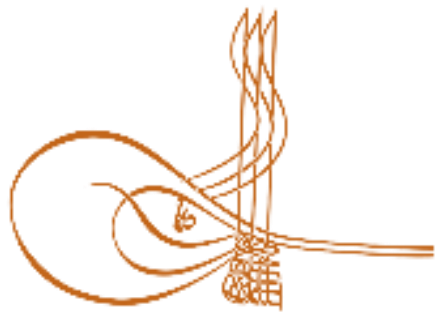

www.turkishstudies.net/social
Turkish Studies - Social Sciences

eISSN: $2667-5617$

Research Article / Araşttrma Makalesi

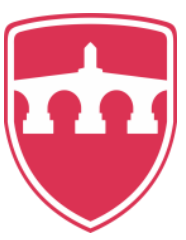

INTERNATIONAL

BALKAN

UNIVERSITY

Sponsored by IBU

\title{
Psikolojik Dayanıklılık Programının (PDP) 15 Temmuz Darbe Girişiminde Eşi Gazi Olan Kadınların Travma Sonrası Stres ve Dayanıklılık Düzeylerine Etkisi
}

\author{
The Effects of Psychological Resiliency Program (PRP) on Post-Traumatic Stress and Resiliency \\ Level of Veteran's Spouses at the 15 July Coup Attempt
}

\author{
Neslihan Arıcı Özcan ${ }^{*}$
}

\begin{abstract}
This quasi-experimental research investigated the effects of Psychological Resiliency Program (PRP) in post-traumatic stress and resiliency level of veteran's spouses at the 15 July Coup Attempt in Turkey. In the study, 28 women whose husbands were veterans due to the 15 July Coup Attempt and who applied to a non-governmental organization named as Association of 15 July between 2016-2017 were reached with the necessary permissions. The study was conducted with 15 women from 28 women having a veteran spouse at 15 July Coup Attempt and obtaining a high score on the Post Traumatic Stress Disorder Checklist Civil Version (PCL-C) and a low score on the Resilience Scale in pre-test assessment. The 15 women in the experimental group were divided into two according to their location $(n=7$ and $n=8)$. Two experimental groups received PRP which is an 8 -session, psychological intervention group program developed by the researcher. To determine the immediate and long-term effects of the PRP program, post-tests were applied on all the participants before PRP, after PRP, and 2,5-months after the PRP, respectively. For repeated measures in data analysis of the research, one-way ANOVA has been used. This study has pointed out that psychological resiliency program was signifacntly effective in reducing post-traumatic stress level in women. Moreover, PRP was significantly effective in increasing psychological resiliency level of women, permanently. The findings have been discussed in accordance with the related literature and recommendations were made to the related parties.
\end{abstract}

\section{Structured Abstract: Introduction}

In today's world the number of post-traumatic stress disorder is increasing especially due to the traumatic terrorist events (Gates, Holowka, Vasterling, Keane, Marx, \& Rosen, 2012; Kessler et al., 2014). These traumatic events have effects on not only individuals who exposed to trauma but also their close environments (spouse, child) (Calhoun, Beckham, \& Bosworth, 2002; Dekel \& Goldblatt, 2008). People living with those traumatized relatives may also experience symptoms of post-traumatic stress disorder such as sleep problems, numbness in the body, etc. (Mansfield, Kaufman, Marshall, Gaynes, Morrissey, \& Engel, 2010). All these effects are also called secondary trauma (Gilbert, 2000). Among the individuals showing secondary trauma symptoms, the spouses of veterans who have been exposed to war or terrorist incidents are the most

\footnotetext{
* Dr. Öğr. Üyesi, İstanbul Medeniyet Üniversitesi, Sağlık Bilimleri Fakültesi, Sosyal Hizmet Bölümü Asst. Prof. Dr., Istanbul Medeniyet University, Faculty of Health Sciences, Department of Social Services ORCID 0000-0002-6169-1445

neslihan.ozcan@medeniyet.edu.tr

Cite as/ Atıf: Arıcı Özcan, N. (2020). Psikolojik dayanıklılık programının (PDP) 15 Temmuz darbe girişiminde eşi gazi olan kadınların travma sonrası stres ve dayanıklılık düzeylerine etkisi, Turkish Studies - Social, 15(3), 919-936. https://dx.doi.org/10.29228/TurkishStudies.40529

Received/Geliş: 12 January/Ocak 2020

Accepted/Kabul: 25 April/Nisan 2020

Checked by plagiarism software

Copyright $(C)$ INTAC LTD, Turkey

Published/Yaym: 30 April/Nisan 2020

CC BY-NC 4.0
} 
common ones (Ahmadi, Azampoor-Afshar, Karami, \& Mokhtari, 2011; Bride \& Figley, 2009; Yambo, Johnson, Delaney, Hamilton, Miller, \& York, 2016). In these studies, secondary trauma of the veteran spouses is explained by many theories such as attachment theory (Johnson, 2002), cognitive behavioral therapy (Monson et al., 2011), family system theory (Nelson-Goff \& Smith, 2005), family attachment theory (Riggs \& Riggs, 2011).

Working with veteran relatives in the approach of attachment theory, it is important to work emotionally and relationally and to utilize safe stabilization in order to deal with the traumatic processes of both the veterans and their relatives (Johnson, 2002). According to cognitive theory of trauma, irrational thought processes and contents that result from trauma have negative effect on close relationships, and they cause communication avoidance and disconnections in the relationships (Monson, Fredman, Macdonald, Pukay-Martin, Resick, \& Schnurr, 2012). Therefore, irrational thoughts are studied with three stages: building trusting relationship via psychoeducation, behavioral interventions for increasing communication, cognitive interventions for handling with irrational thoughts (Monson, Gradus, La Bash, Griffin, \& Resick, 2009a).

Moreover, in terms of systematic family therapy, veteran spouses may feel psychologically uneasy since their spouse's functions and roles change in the family (Boss, 2007). The functions and roles of veterans' spouses can be worked with salutogenesis approach, particularly on resiliency. Resiliency is defined as the ability to resist the individual's destructive life difficulties, to recover, to strengthen this process with more resources (Walsh, 2006). Numerous models such as family attachment network model (Kozlowska \& Hanney, 2002; Riggs \& Riggs, 2011), REACH based on the Multi-Family Program (Sherman, Fischer, Sorocco, \& McFarlane, 2009) are found to be effective on post-traumatic stress disorder of veterans' spouses and strengthening family relationships. The July 15 Coup Attempt is also a terrorist incident, and it is known that there are more than 2,700 veterans (15 July Association, 2020). Therefore, a psychoeducational program conducted with the spouses of the veterans would be important. However, no experimental study addressed on the post-traumatic stress problem in the context of resilience, which was observed in the veterans's spouses, especially in the national literature. Therefore, the purpose of this study is to examine the effects of Psychological Resiliency Program (PRP) in post-traumatic stress and resiliency level of veterans's spouses at the 15 July Coup Attempt in Turkey.

\section{Methods}

This quasi-experimental study attempted to reveal the effects of PRP on the posttraumatic stress and resilience levels that was applied on women whose spouses are veterans in the July 15 Coup Attempt. The study was quasi-experimental design without control group. Thus it was handled with single-factor repeated measurements with pre, post, and follow-up tests (Büyüköztürk, 2002). In the study, 28 women whose husbands were veterans due to the 15 July Coup Attempt and who applied to a non-governmental organization named as Association of 15 July between 2016-2017 were reached with the necessary permissions. The study was conducted with 15 out of 28 women with the criterias of being spouse of a veteran at 15 July Coup Attempt and obtaining a high score on the Post Traumatic Stress Disorder Checklist Civil Version (PCL-C) and a low score on the Resilience Scale in pre-test assessment. The 15 women in the experimental group were divided into two according to their location $(n=7, n=8)$. Two experimental groups received PRP which was an 8session, psychoeducation group program developed by the researcher. To determine the immediate and longterm effects of the PRP program, post-tests were applied on all the participants before PRP, after PRP, and 2,5months after the PRP, respectively.

\section{Results}

To use parametric tests in the analysis of the homogeneity, normal distribution, skewness, and kurtosis values were tested and showed the normal distribution. Thus, for repeated measures in data analysis of the research, one-way ANOVA was used. This study pointed out that PRP was significantly effective in decreasing post-traumatic stress level of 15 July Coup Attempt veterans' spouses for two experimental groups, permanently $\left(F_{(2-12)}=23.80 p<.01\right), \quad\left(F_{(2-14)}=23.10 p<.01\right)$. Moreover, PRP was significantly effective in increasing resiliency level of 15 July Coup Attempt veterans' spouses permanently $\left(F_{(2-12)}=82.658 p<.01\right),\left(F_{(2-}\right.$ $\left.{ }_{14)}=78.981 p<.01\right)$. Tukey Test was performed and there was a significant difference between the average scores obtained from PCL-C and Resilience Scale in pretests of the experiment I \& II groups and the average scores obtained from the post-test and follow-up test measurements. 


\section{Discussion and Conclusion}

The first result of the research; it was effective in reducing post-traumatic stress levels of veterans' spouses in the PRP's experimental group. The PRP was prepared considering the principles of three approaches (attachment theory, cognitive behavioral approach, and systemic family therapy). Many studies based on these three approaches were effective in reducing post-traumatic stress levels of veterans's spouses and it supports the findings of this research (Kozlowska \& Hanney, 2002; Riggs \& Riggs, 2011; Sherman et al., 2009).

The second main result of the research; it was effective in increasing the resilience levels of veterans's spouses in the PRP experimental group. In the PRP applied in this study, the risks (anger, isolation), resources (social and emotional support, etc.) and the communication of the relations of the veterans' spouses were emphasized, and the resilience levels of the participants increased. In the literature, many studies (Charuvastra \& Cloitre, 2008; Riggs \& Riggs, 2011) and programs for effective resilience program [Strong Bonds for Couples and Families (Stanley et al., 2005), REACH (Sherman et al., 2009)] were parallel with this finding.

Taken consideration into all these results of this research, there are various limitations and suggestions. The findings of this study are limited to the results obtained from women whose spouses are veterans at the July 15 Coup Attempt. This study can be applied and tested on individuals who suffer from post-traumatic stress disorder due to war and terrorism. In this study, there was no control group since the experimental group should be applied psychoeducation immediately. In future studies, this study can be tested with the control group and the effectiveness of the research can be strengthened.

Keywords: Post-Traumatic Stress, Resiliency, Psychological Resiliency Program

Öz: Bu araştırma, Türkiye'deki 15 Temmuz Darbe Girişiminde eşi gazi olan kadınlara uygulanan Psikolojik Dayanıklılık Programının (PDP), travma sonrası stres ve dayanıklılık düzeylerine etkisini incelemek amacı ile yapılan yarı deneysel bir çalışmadır. Araştırmada 15 Temmuz Darbe Girişimi olayında eşi travmatik yollarla gazi olan ve bu konuda çalışan 15 Temmuz Derneğine 2016-2017 yılları arasında başvuran 28 kadına gerekli izinler alınarak ulaşılmıştır. 15 Temmuz Derneğinden ulaşılan 28 gazi eşinden, ön testlerinde yer alan Post Travmatik Stres Bozukluğu Soru Listesi Sivil Versiyonu (PTSB-SLSV) ölçeğinde ortalamadan yüksek ve Kendini Toparlama Gücü Ölçeğinde (KTGÖ) ortalamadan düşük puan alan toplam 15 kadın yer almıştır. Deney grubundaki 15 kadın, bulundukları semte göre ikiye ayrılmıştır ( $n=7$ ve $n=8$ ). PTSB-SLSV ve KTGÖ'den alınan puanlara göre oluşturulan bu iki deney grubuna araştırmacı tarafindan geliştirilen 8 oturumluk, psikolojik müdahale grup programı olan PDP uygulanmıştır. Tüm katılımcılara program öncesi, sonrası ve 2,5 ay izlemede PTSB-SLSV ve KTGÖ ölçekleri uygulanmış ve programın etkisi ve kalıcılığı değerlendirilmiştir. Araştırmanın veri analizinde tekrarlı ölçümler için tek yönlü ANOVA kullanılmıştır. Yapılan bu çalışma ile iki temel sonuca varılmıştır; psikolojik dayanıklılık programı kadınların travma sonrası stres düzeylerini azaltmada etkili olmuştur. Bununla birlikte bu programın, kadınların psikolojik dayanıklılık düzeylerini arttırmada etkili olduğu ve bu etkinin kalıcı olduğu görülmüştür. Araştırmanın bulguları, ilgili alanyazın doğrultusunda tartışılmış ve çeşitli öneriler sunulmuştur.

Anahtar Kelimeler: Travma Sonrası Stres Bozukluğu, Psikolojik Dayanıklılık, Psikolojik Dayanıklılık Program 1

\section{Giriş}

Travmatik yaşantılar (savaş, taciz, istismar, deprem) yüzyıllardır var olmasına rağmen 21 . yüzyılın başından itibaren klinik ve deneysel çalışmaların odak noktası olmuştur (Nelson-Goff ve Smith, 2005). Günümüzdeki çalışmalar travma sonrası stres bozukluğunun dünya genelinde yaygınlığının giderek arttığını ve her beş kişiden birinin travma sonrası stres bozukluğu belirtileri gösterdiğini dile getirmektedir (Kessler, 2000; Kessler vd., 2014). Birçok çalışmada (Calhoun, Beckham ve Bosworth, 2002; Dekel ve Goldblatt, 2008; Dekel, Goldblatt, Keidar, Solomon ve Polliack, 2005; Dekel ve Solomon, 2006; Galovskia ve Lynosa, 2004) travmatik yaşantıların sadece travmaya birebir maruz kalan bireyleri değil bireylerin yakın çevresini de (eşi, çocuğu, arkadaşı) etkilediği dile getirilmektedir. Kısacası travmatik yaşantıların bulunduğu sistemde bulaşıcı bir etkisi 
vardır (Bride ve Figley, 2009; Johnson, 2002; Nelson-Goff ve Smith, 2005). Travmatik yaşantılar yaşayan bireylerle yaşayan yakınlarında da uyku sorunu, nefes almada güçlük, bedende uyuşma, baş ağrısı, diğerlerine güvenmede zorluk, zihne gelen istemsiz düşünceler görülebilmektedir (Mansfield, Kaufman, Marshall, Gaynes, Morrissey ve Engel, 2010). Bütün bu etkilere ikincil travma denilmektedir (Gilbert, 2000). İkincil travmada birey, travma sonrası stres bozukluğunun belirtilerini göstermektedir. İkincil travma belirtileri gösteren bireyler arasında en çok savaş veya terör olaylarına maruz kalmış bireylerin (gazi) eşleri yer almaktadır (Ahmadi, Azampoor-Afshar, Karami ve Mokhtari, 2011; Chandra vd., 2010; Riggs ve Riggs, 2011).

Savaş ve terör olaylarına maruz kalan bireylerin (gazi) eşlerinin ikincil travma yaşadığını belirten birçok çalışma (Ahmadi vd., 2011; Bride ve Figley, 2009; Calhoun vd., 2002; Dekel ve Goldblatt, 2008; Dekel vd., 2005; Dekel ve Solomon, 2006; Dirkzwager, Bramsen, Adèr ve van der Ploeg, 2005; Francisković vd., 2007; Galovskia ve Lynosa, 2004; Gewirtz, Polusny, DeGarmo, Khaylis ve Erbes, 2010; Manguno-Mire vd., 2007; Monson, Taft, Freedman, 2009b; Yambo vd., 2016) bulunmaktadır. Bu çalışmalarda gazi eşlerinin ikincil travma yaşaması birçok teori ile açıklanmaktadır. Bu teoriler; bağlanma teorisi (Johnson, 2002), bilişsel davranış̧̧ı terapi (Monson vd., 2011), aile sistem teorisi (Nelson-Goff ve Smith, 2005), aile bağlanma teorileridir (Riggs ve Riggs, 2011).

Bağlanma teorisine göre travma sonrası stres sorunu ilişkisel bağlamda oluşmakta ve travma sonrası stres sorununun sonuçları ilişkilere bulaşmaktadır (Johnson, 2002). Johnson'a göre (2002) ilişki; travma sonrası stres yaşayan bireyin travmasıyla başa çıkmasına olumlu etki etmiyorsa bireyin travmayı yeniden yaşamasına yol açabilmektedir. Travma sonrası stres belirtilerinde görülen izolasyon, azalan duygusal ifade ve kişiler arası bağlantıların bozulmaması için ilişkiyi yeniden yapılandırmak gerekmektedir. Bu bağlamda bağlanma teorisi odaklı yaklaşımda gazi yakınları ile çalışırken hem gazinin hem de gazi yakınının travmatik süreçlerini ele almak için duygu odaklı ve ilişkisel çalışmak (Emotional Focused Therapy: EFT) ve ilişkiyi güvenli bir stabilizasyona getirmek önemlidir (Erbes, Polusny, MacDermid ve Compton 2008; Johnson, 2002).

Gazi yakınları ve gazilerle travma sonrası stres sorununu etkin ele alan bir diğer teori de bilişsel davranışçı terapiden ortaya çıkan bilişsel-davranışsal birleştirme terapisidir (behavior cognitive conjoint therapy) (Monson vd., 2012; Monson, Gradus, La Bash, Griffin ve Resick, 2009a; Monson, Schnurr, Stevens ve Guthrie, 2004b). Bilişsel-davranışsal birleştirme terapisine göre travma sonrası stres bozukluğu yaşayan bireyin travma sonrası stresi ile yakın ilişkide yaşadığı sorunlar arasında anlamlı ve karmaşık ilişkiler vardır. Başka bir ifade ile bilişsel olarak travmadan kaynaklanan mantıksız düşünce süreçleri ve içerikleri etkileşimsel olarak yakın ilişkiyi etkilemekte ve davranışsal olarak da bireyin yakın ilişkilerinde iletişimde kaçınmalara ve iletişim kopukluklarına neden olabilmektedir (Monson vd., 2012; Monson, Gradus, La Bash, Griffin ve Resick, 2009a; Monson, Schnurr, Stevens ve Guthrie, 2004b). Bu yüzden travma sonrası stres bozukluğu yaşayan gazi veya gazi yakını ile bu sorun 15 seansta üç aşamalı olarak ele alınmaktadır. İlk aşamada psikoeğitim ve yakın ilişkide güven inşası; ikinci aşamada ilişkideki iletişimi ve memnuniyeti artırmak amacı ile davranışsal müdahaleler; üçüncü aşamada ise mantıksı düşünceleri ele almak ve değiştirmek amacı ile bilişsel müdahaleler yer almaktadır (Monson vd., 2011; Monson vd., 2009a; Monson vd., 2009b).

Aile sistem teorisi de gazi eşleri ile çalışmada oldukça etkindir (Boss ve Couden, 2002). Aile sistem teorisine göre gazi eşleri belirsiz bir kayıp (ambigous loss) yaşayabilmektedir. Gazi eşleri aile içinde eşlerinin işlevleri ve rolleri değiştiğinden eşlerinin varlığını fiziksel hissederken psikolojik olarak varlıklarını hissedemeyebilmektedirler (Boss, 2007; Nelson-Goff ve Smith 2005; Sayers, Farrow, Ross ve Oslin, 2009). Bu bağlamda gazi eşlerinde, eşlerinin işlevlerinin ve rollerinin değişmesinden ötürü olan yaşamsal belirsizlik travma sonrası stres belirtilerinin görülmesine yol açabilmektedir. Gazi eşlerinin ve yakınlarının travma sonrası stres belirtilerini ele almak için Nelson- 
Goff ve Smith (2005) tarafından geliştirilen Çiftin Travma Sonrası Strese Uyum Modeli (The Couple Adaptation to Traumatic Stress CATS) bulunmaktadır. Bu model üç düzeyde (bireysel düzeydeki işlevi, travmayı etkileyen faktörler ve kaynaklar, çift olarak ilişkisel işlev dinamikleri) ele alınmaktadır. Bireysel düzeydeki işlevinde hem gazi hem de gazi yakınının/eşinin travma belirtileri değerlendirilmektedir. Travmayı etkileyen faktörler (yaş, eğitim, önceki travmaları) ve kaynaklar (başa çıkmaları, destekleri) düzeyinde hem gazi hem de gazi eşinin travmasını etkileyen etmenler ve travmasını ortadan kaldıracak kaynaklar ele alınmaktadır. Çift olarak ilişkisel işlev dinamikleri düzeyinde ise travmanın hem gazi hem de gazi eşinin ilişkilerindeki bağlılığı, durağanlı̆̆ uyumu, memnuniyeti, iletişimi, rolleri, destek sistemlerini nasıl etkilediği ve nasıl olumlu etkileyeceği ele alınmaktadır (Nelson-Goff ve Smith, 2005).

21. yüzyılda aile sistem teorisi tabanlı geliştirilen modellerde (Walsh, 2003; 2006) zorluklarla başa çıkma şekilleri "patogenez" anlayışla ele alınmak yerine "salutogenez" anlayışla ele alınmıştır. Zorluklarla başa çıkmada çözüm odaklı yaklaşımı içinde barındıran en önemli kavram ise psikolojik dayanıklılıktır. Walsh $(2003 ; 2006)$ psikolojik dayanıklılığ 1 bireyin yıkıcı yaşamsal zorluklarına karşı koyabilme, yeniden toparlanabilme, güçlenme ve daha çok kaynakla bu süreçten çıkabilme yeteneği olarak tanımlamıştır. Ayrıca Walsh, psikolojik dayanıklılı̆ğın risk, yatkınlık ve koruyucu faktörlerin ve bireysel, ailesel ve sosyo-kültürel etmenlerin etkileşiminden oluşan bir süreç olduğunu ifade etmiştir. Bu bağlamda gazinin veya gazi yakınının psikolojik anlamda dayanıklı olmalarında risk, yatkınlık ve koruyucu faktörleri ve ilişkileri çok önemli bir etkendir (Charuvastra ve Cloitre, 2008).

Gazi ve gazi yakınları ile travma sonrası stres bozukluğunu psikolojik dayanıklılık bağlamında ele alan aile bağlanma ağı modeli vardır (Kozlowska ve Hanney, 2002; Riggs vd., 2009; Riggs ve Riggs, 2011). Bu model sistem teorisini ve bağlanma teorisini entegre ederek gazi ve gazi yakını ile yeniden yaşama uyum sağlamayı ele almaktadır. Bu modelde ailenin birbirleriyle olan ilişkilerinde çoklu bağlanma olduğu dile getirilmekte ve bu bağlanmalar çoklu sistem (bireysel, ikili, alt sistem-geniş sistemle entegrasyonu) ile ele alınmaktadır (Kozlowska ve Hanney, 2002; Riggs, Monson, Glynn ve Canterino, 2009; Riggs ve Riggs, 2011). Bu modelde her bir sistemi psikolojik dayanıklı kılma amacı ile her bir sistemin başa çıkma stratejileri, iletişimlerinin niteliği ve niceliği, rollerindeki esnekliği, sosyal destek kaynakları ve toplumsal etkinliklere katılma durumu ele alınmaktadır (Kozlowska ve Hanney, 2002; Riggs vd., 2009; Riggs ve Riggs, 2011).

Gaziyi ve gazi yakınlarındaki travma sonrası stres bozukluğunu psikolojik dayanıklılık bağlamında etkin ele alan bir diğer model de Çoklu Aile Programına (Multifamily Group Program) dayalı geliştirilen Sağlıklı ve İlgilenen Aileleri Eğitme ve Yardım Etme Programıdır (Reaching Out to Educate and Assist Caring, Healthy Families-REACH) (Sherman, Fischer, Sorocco ve McFarlane, 2009). Bu program 9 ay süren 3 bölümden oluşmaktadır. İlk bölüm 4 hafta sürmekte ve gazi aileleri kendi aralarındaki ilişkiyi güçlendirmek için bir araya gelmektedir. İkinci fazı 6 hafta sürmektedir ve gazi aileleri bir araya gelerek öfke yönetimi vb. konularda eğitimler almaktadır. Üçüncü bölümü ise gazi ailelerinin aylık toplandığı ve belli konuları ele aldıkları bir grup çalışması şeklinde olmaktadır (Sherman vd., 2009). Çoklu Aile Programına benzer psikolojik dayanıklılık bağlamında geliştirilen ve gazilerde ve ailelerinde etkin bir diğer program da Çiftler ve Aileler İçin Güçlü Bağlar (Strong Bonds for Families and Couples) programıdır. Bu programda da çiftlerin ve ailelerin sorunlar yaşamasına sebep olabilecek riskleri ve sorunlarla başa çıkmasını sağlayacak kaynakları ele alınmaktadır (Stanley vd., 2005).

Ulusal literatüre baktığımızda ise gazilerde travma sonrası stresi (Güloğlu ve Irmak, 2013) ele alan ve gazi yakınlarında da depresyonu ve psikolojik dayanıklılığı ele alan (Duran ve Ünsal, 2014) az sayıda betimsel çalışma yer almaktadır. Ancak gazi yakınlarında travma sonrası stresi ve psikolojik dayanıklılığı ele alan deneysel bir çalışmaya rastlanmamaktadır. 
Dünya genelinde terör olayları ve terör olaylarına maruz kalan gazi bireylerin, gazi yakınlarının sayısı ve beraberinde bu bireylerin travma sonrası stres bozukluğu geçirmeleri giderek artmaktadır (Gates vd., 2012; Kessler vd., 2014; Richardson, Frueh ve Acierno, 2010; Sundin, Fear, Iversen, Rona ve Wessely, 2010). Terör olayına maruz kalan gazi yakını, özellikle eşi, terör olayına maruz kalan gazi kadar etkilenmektedir (Calhoun vd., 2002; Dekel ve Goldblatt, 2008; Dekel ve Solomon, 2006). 15 Temmuz Darbe Girişimi olayı da bir terör olayıdır ve bu olayda 2 bin 700'den fazla gazi olduğu bilinmektedir (15 Temmuz Derneği, 2020). Bu yüzden gazi yakını eşlere yapılacak bir müdahale önemlidir. Ancak özellikle ulusal alan yazınında gazi yakınlarının eşlerinde görülen travma sonrası stres sorununu psikolojik dayanıklılık bağlamında ele alan deneysel çalışmaya rastlanmamıştır. Bu bağlamda bu çalışmanın amacı Psikolojik Dayanıklılık Programının kadınların travma sonrası stres ve dayanıklılığı düzeylerine etkisini incelemektir. Araştırmada bu amaçlara ulaşmak için aşağıda verilen denenceler test edilmiştir.

\section{Denenceler}

$\mathrm{H}_{1}$. Psikolojik Dayanıklılık Programı deney grubundaki kadınların travma sonrası stres düzeylerini azaltmada anlamlı düzeyde etkili olacaktır ve bu etki programın tamamlanmasından iki buçuk ay sonra yapılacak ölçümlerde de devam edecektir.

$\mathrm{H}_{2}$. Psikolojik Dayanıklılık Programı deney grubundaki kadınların psikolojik dayanıklılık düzeylerini artırmada anlamlı düzeyde etkili olacaktır ve bu etki programın tamamlanmasından iki buçuk ay sonra yapılacak ölçümlerde de devam edecektir.

\section{Yöntem}

\section{Araştırma Deseni}

$\mathrm{Bu}$ araştırma, 15 Temmuz Darbe Girişiminde eşi gazi olan kadınlara uygulanan PDP'nin kadınların travma sonrası stres ve psikolojik dayanıklılık düzeylerine etkisini ortaya koymaya çalışan yarı deneysel bir çalışmadır. Araştırmada kontrol grupsuz ön, son ve izleme testli tek faktörlü tekrarlı ölçümlerin olduğu zayıf deneysel desen ile ele alınmıştır. Bu desende, bağımsız değişken zamanını (üç zaman noktası: ön-test, son-test ve izleme test) gösterirken, bağımlı değişken ise araştırmada yer alan ölçeklerden elde edilen skorların düzeyleri (Post-Travmatik Stres Bozukluğu Soru Listesi Sivil Versiyonu, Kendini Toparlama Gücü Ölçeği) göstermektedir (Büyüköztürk, 2002).

Tablo 1: Araştırmanın Deseni

\begin{tabular}{lllll}
\hline Gruplar & Ön test & İşlem & Son test & İzleme \\
\hline Deney I ve II & PTSB & PDP & PTSB & PTSB \\
& KTGÖ & & KTGÖ & KTGÖ \\
\hline
\end{tabular}

PTSB: Post-Travmatik Stres Bozukluğu Soru Listesi Sivil Versiyonu, KTGÖ: Kendini Toparlama Gücü Ölçeği, PDP: Psikolojik Dayanıklılık Programı

\section{Katılımcilar}

Araştırmaya katılacak kadınları belirlemek amacıyla İstanbul'da eşini 15 Temmuz Darbe Girişimi olayında kaybeden veya eşi 15 Temmuz Darbe Girişimi olayında gazi olan bireylerle çalışan 15 Temmuz Derneğine 2016-2017 yıllarında başvurulmuş ve izin alınmıştır. Araştırmada bu bağlamda uygun örnekleme yöntemi tercih edilmiştir. 15 Temmuz Derneğine başvuran, Türk uyruklu ve eşi travmatik yollarla (tank ezme, silahla kol, bacak kaybı) gazi olan 28 kadına 15 Temmuz Derneğinden ulaşılmıştır.

Gazi eşi olan kadınlar araştırmacı ve 15 Temmuz Derneği tarafından araştırma hakkında yazılı ve sözlü olarak bilgilendirilmiş, sonrasında kadınların travma sonrası stres ve psikolojik dayanıklı1ık düzeylerini belirlemek amacı ile sırasıyla Post-Travmatik Stres Bozukluğu Soru Listesi Versiyonu (PTSB-SLSV) ve Kendini Toparlama Gücü (KTGÖ) ölçekleri kadınlara uzmanlar 
eşliğinde uygulanmıştır. Uygulama sonucunda PSTB-SLVS'den yüksek puan alan $(\bar{X}=47.53)$ $(\mathrm{Ss}=15.08)$, KTGÖ'den ortalamadan düşük puan alan $(\bar{X}=125.53)(\mathrm{Ss}=19.65) 15$ kişinin deney grubunda yer alması belirlenmiştir. Deney grubunda yer alan 15 kadın ulaşım nedeniyle bulundukları semte göre ikiye ayrılmışlardır. Bir grupta 8 kişi bir grupta ise 7 kişi bulunmaktadır. 28 kadından ölçeklerden istenilen puanı alamayan 13 kadına ise 1 oturumluk psikoeğitim verilmiştir.

Deney grubunun ( $\mathrm{n}=7)$ ilkinde yaş aralı̆ $\breve{g}_{1} 30-53$ ( $\left.\bar{X}=39.85 \mathrm{Sd}=9.47\right)$, ikincisinde $(\mathrm{n}=8)$ ise yaş aralığ $29-48$ ' $\operatorname{dir}(\bar{X}=38.75 \mathrm{Sd}=7.94)$. Ayrıca deney grubunun $(\mathrm{n}=7)$ ilkinde katılımciların $\% 71,4$ 'ü ilkokul mezunu, \%14,3'ü ortaokul, \%14,3'ü ise lise iken; deney grubunun ikincisinde $(n=8)$ katılımcilarının \%62,5'i ilkokul mezunu, \%12,5'i ortaokul, \%25'i ise lise mezunudur. Her iki gruptaki bireylerin çoğu çalışmamaktadır. Son olarak her iki gruptaki bireylerin en az 1 çocuğu bulunmaktadır. Demografik özelliklere ait bilgilerin özeti Tablo 2'de verilmiştir.

Tablo 2: Deney Gruplarında Yer Alan Katılımcıların Demografik Özellikleri

\begin{tabular}{lccclcccccccc} 
& Yaş & Yas & Yas & Eğitim & \multicolumn{3}{c}{ Çocuk } & \multicolumn{3}{c}{ Çalışma } \\
& Aralığı & $\mu$ & Sd & Durumu & n & $\%$ & Sayısı & n & $\%$ & Durumu & n & $\%$ \\
\hline Deney & $30-53$ & 39.85 & 9.47 & İlkokul & 5 & 71,4 & 1 & 1 & 14,3 & var & 0 & 0 \\
Grubu I & & & & Ortaokul & 1 & 14,3 & 2 & 2 & 42,9 & yok & 7 & 100 \\
$(\mathrm{~N}=7)$ & & & & Lise & 1 & 14,3 & $3 \geq$ & 3 & 42,9 & & & \\
\hline Deney & $29-48$ & 38.75 & 7.94 & İlkokul & 5 & 62,5 & 1 & 1 & 12,5 & var & 1 & 12,5 \\
Grubu II & & & & Ortaokul & 1 & 12,5 & 2 & 1 & 12,5 & yok & 7 & 87,5 \\
$(\mathrm{~N}=8)$ & & & & Lise & 2 & 25 & $3 \geq$ & 6 & 75 & & & \\
\hline
\end{tabular}

\section{Veri Toplama Araçları}

Post Travmatik Stres Bozukluğu Soru Listesi Sivil Versiyonu (PTSB-SLSV): Bu araştırmada travma sonrası stres düzeylerini ölçmek amacıyla Weathers ve arkadaşları (1993) tarafindan geliştirilen ve Koşabaşoğlu vd. (2005) tarafindan Türkçe'ye uyarlanan "Post Traumatic Stress Disorder Checklist Civil Version" kullanılmıştır. 17 maddelik, üç alt boyutlu ve 5 Likert tipi ölçekte en yüksek puan 85 ve en düşük puan ise 17'dir. Orijinal ölçeğin Missisipi PTSB ölçeği ile uyum geçerliliği .85 ile .93 arasında değişmektedir (Weathers vd., 1993). Orijinal formun güvenirlik çalışmasında Cronbach alfa iç tutarlılık güvenirlik katsayı toplam puanı için .94 ile .97 arasında (Weathers vd., 1993) değişmektedir. Üç gün arayla uygulanan test-tekrar test güvenirlik katsayıları ölçeğin bütünü için .96 ve 1 hafta arayla yapılan uygulamalarda ise ölçeğin bütünü için .88 olarak hesaplanmıştır. Türkçe ölçeğin ve alt ölçeklerin klinisyen tarafından uygulanan TSSB-5 ölçeği ve alt ölçekleri ile korelasyonu değerlendirildiğinde toplam puanı $(r=.65, p<0.001)$, yeniden yaşama puanı $(r=.61, p<0.001)$ ve aşırı uyarılma puanının $(r=.56, p<0.001)$ korelasyon katsayılarının iyi derecede olduğu görülmüsstür. Ölçeğin kesim puanının ise 22-24 arasında olduğu ve duyarlılık ve özgüllük değerlerinin her ikisinin de \%70'ten yüksek olduğu görülmüş̧ür. Türkçe ölçeğin güvenirlik katsay1 .92 , madde toplam korelasyon katsayıları ise .37 ile. 73 arasında değişmektedir.

Kendini Toparlama Gücü Ölçeği (KTGÖ): Bu araştırmada psikolojik dayanıklılık düzeylerini belirlemek amacıyla Wagnild ve Young (1993) tarafından geliştirilen ve Terzi (2006) tarafından Türkçe'ye uyarlanan "Resilience Scale" kullanılmıştır. 24 maddelik ve 7'li Likert tipli bir ölçektir. Ölçeğin yapı geçerliği faktör analizi ile saptanmış ve faktörlerin her bir değişken üzerindeki ortak varyansı .469 ile .740 arasında olduğu görülmüştür. KTGÖ'nin özdeğeri 1'den büyük olan 7 faktör verdiği belirlenmiştir. Yapılan benzer ölçekler geçerliği çalışmasında ise KTGÖ ile Genelleştirilmiş Özyeterlik Ölçeği arasında anlamlı bir ilişki bulunmuştur $(r=.83)$. Ölçeğin cronbach alpha güvenirlik katsayısı .82 ; test-tekrar test güvenirlik katsayısı $r=.84$ olarak saptanmıştır. Ölçeğin madde toplam korelasyonları ise .03 ile .69 arasında bulunmuştur. KTGÖ'nün üniversite öğrencilerinde psikolojik dayanıklılık düzeylerini belirlemede geçerli ve güvenilir bir ölçektir. 


\section{Deneysel İşlem \\ “Psikolojik Dayanıklılık Programı" Kapsamı}

PDP araştırmacı tarafından geliştirilen, travma sorunu yaşayan gazi eşi olan kadınların travma sonrası stres düzeylerini azaltmaya ve psikolojik dayanıklılık düzeylerini arttırmaya yönelik bir psikolojik müdahale grup programıdır. PDP geliştirilmeden önce gazilerde ve gazi yakınlarında travma sonrası stres ve psikolojik dayanıklılığına yönelik kuramsal bilgiler toplanmış, bu iki kavram hakkında yapılmış uygulamalar ve programlar incelenmiştir (Kozlowska ve Hanney, 2002; Riggs ve Riggs, 2011; Sherman vd., 2009; Stanley vd., 2005). Literatür detayli incelendiğinde gazi yakınlarında travma sonrası stres sorununun çok boyutlu olduğu, birkaç kuramsal yaklaşımla beraber ele alınması gerektiği anlaşılmıştır (Sherman vd., 2009; Stanley vd., 2005). Bu kuramlar giriş bölümünde de belirtildiği gibi bağlanma kuramı (Erbes vd., 2008; Johnson, 2002), bilişsel davranışç1 kuram (Monson vd., 2004a; Monson vd., 2009b; 2012) ve sistemik aile terapisi yaklaşımlarıdır (Boss, 2007; Kozlowska ve Hanney, 2002; Nelson-Goff ve Smith 2005; Sayers vd., 2009; Sherman vd., 2009; Riggs ve Riggs, 2011).

Araştırmalarda özellikle gazilerin travma sonrası stres belirtileri ile çalışırken gazilerde görülen izolasyon ve azalan duygusal ifadelerin bireylerin kişiler arası bağlantılarını olumsuz etkilediği için ilk olarak ilişkilerini güvenli bir stabilizasyona getirmek önemlidir (Erbes, Polusny, MacDermid ve Compton 2008; Johnson, 2002). Daha sonra da bireyin travmasinı yeniden yapılandırmasına ve yaşama uyum sağlamasına, kısacası bilişsel süreçlerine vurgu yapılmaktadır (Monson vd., 2004; Monson, 2009a; 2012). En son olarak da bütün bunlar aile sistemindeki her bir bireyin riskleri ve kaynakları bireysel veya gruplar olarak ele alınmaktadır (Nelson-Goff ve Smith 2005; Sayers vd., 2009; Sherman vd., 2009; Riggs ve Riggs, 20011). Bu bağlamda bu çalışmada bağlanma kuramının önerdikleri bilişsel davranışçı terapinin ve sistemik aile terapisinin uygulama etkinliklerine yer verilmiştir.

Bu üç kuramsal yaklaşımla beraber PDP'de birçok farklı kuramın tekniğini de (davranışsal tekniklerden rahatlama ve gevşeme teknikleri; bilişsel davranışçı kuramın tekniklerinden irrasyonel düşünceyi tespit etme ve değiştirme ve görselleri kullanma; duygu odaklı yaklaşımlardan yazma; gestalt terapi tekniklerinden bedene odaklanma, çift veya tek sandalye; çok kuşaklı aile terapisi tekniklerinden fotoğraflarla çalışma) kullanılmıştır. Bu bağlamda bu program hazırlanırken eklektik bir yaklaşımla bu üç yaklaşımdan ve farklı kuramların tekniklerinden büyük oranda yararlanılmış ve özgün bir psiko-eğitim grup programı oluşturulmaya çalışılmıştır. Bu inceleme süreciyle eş zamanlı olarak araştırmanın bağımlı değişkenlerinden olan psikolojik dayanıklılık alanındaki kuramsal ve uygulamaya yönelik literatür de analiz edilmiş ve bu konuda yapılmış kuramsal ve uygulamalı çeşitli çalışmalar (Boss, 2007; Charuvastra ve Cloitre, 2008; Kozlowska ve Hanney, 2002; Nelson-Goff ve Smith, 2005; Sayers vd., 2009; Sherman vd., 2009; Stanley vd., 2005; Riggs ve Riggs, 2011, Walsh, 2006) da dikkate alınarak program düzenlenmiştir.

\section{“Psikolojik Dayanıkılık Programı” İçeriği}

PDP sekiz oturumluk bir psikolojik müdahale grup programıdır. Oturumlarda travma sonrası stres sorununa ve psikolojik dayanıklılığa yönelik 24 etkinlik yer almaktadır. Her oturumda toplam üç etkinlik vardır ve etkinliklerin ortalama süresi 20-25 dakikadır. Oturumlardaki ilk etkinlik 1sınmaya, ikinci etkinlik oturumun esas amacina, üçüncü etkinlik ise oturumdan olumlu duygularla ayrılmaya yöneliktir. Isınmaya yönelik etkinliklerden bir tanesi "Mekânda Kendinle Gezinti" etkinliğidir. Bu etkinlikte bireyin fiziksel ve ruhsal açıdan mekâna varması ele alınmıştır. Programın amacına yönelik travma etkinliklerinden bir tanesi de "Dırdırcı Teyze" etkinliğidir. Bu etkinlikteki amaç zor yaşantı ile beraber bireyde oluşan mantıksız inançları sorgulatmak ve daha mantıklı bir çerçevede ele almayı sağlamaktır. Oturumdan olumlu duygularla ayrılmaya ve bireyin kaynaklarını fark etmeye yönelik etkinliklerden bir tanesi de "Güç Yüzüğüm" etkinliğidir. Bu etkinlikte bireyin yaşamındaki zorluklar karşısında kullandığı ancak fark etmediği güçlü yanını bireye fark ettirmek ve 
bu yanını bedeninde veya parmağında bir yüzüğe yerleştirmek amaçlanmıştır. Bütün bu etkinliklerin yer aldığı oturumların konuları aşağıdaki Tablo 3 'te sunulmuştur.

Tablo 3: Psikolojik Dayanıklılık Programının Oturumları

\begin{tabular}{|c|c|}
\hline 1.Oturum & $\begin{array}{ll} & \text { Tanışma, Kaynaşma } \\
\text { - } & \text { Travma Sonrası Stres Sorununu Ortak Paydada Tanımlama }\end{array}$ \\
\hline 2. Oturum & 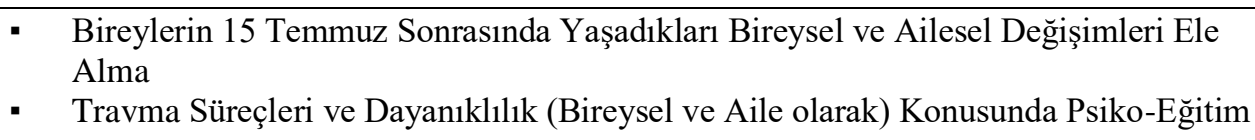 \\
\hline 3. Oturum & $\begin{array}{l}\text { - } 15 \text { Temmuz Darbe Girişimi Olayını Hatıllatan İpuçları ve Duyguları Ele Alma } \\
\text { - Travma Sorunuyla Başa Çıkma Kaynaklarını ve Dayanıklılıklarını Ele Alma }\end{array}$ \\
\hline 4.Oturum & $\begin{array}{l}\text { - } 15 \text { Temmuz Darbe Girişimi Olayında Hissedilen Duyguları Ele Alma ve Yüzleşme } \\
\text { - } \quad \text { Duygusal Rahatlamayı Ele Alma } \\
\text { Duygusal Dayanıklılığını Artıracak Kaynaklarını Fark Ettirme }\end{array}$ \\
\hline 5.Oturum & $\begin{array}{l}\text { - } 15 \text { Temmuz Darbe Girişimi Olayı Karşısında Duyumsanan Bedensel Tepkileri Ele } \\
\text { Alma } \\
\text { - } \quad \text { Bedensel Rahatlamayı Ele Alma } \\
\text { Bedensel Dayanıklılığını Artıracak Kaynakları Fark Ettirme }\end{array}$ \\
\hline 6. Oturum & $\begin{array}{l}\text { - } 15 \text { Temmuz Darbe Girişimi Olayı Sonrasında Gelişen Mantıksız Olumsuz } \\
\text { Düsünceleri Ele Alma } \\
15 \text { Temmuz Darbe Girişimi Olayının Sonrasında Gelişen Olumsuz Duyguların, } \\
\text { Duyumsamaların ve Mantıksız Olumsuz Düşüncelerin Kısa ve Uzun Vadeli } \\
\text { Davranışları Etkilediğini Ele Alma }\end{array}$ \\
\hline 7. Oturum & $\begin{array}{l}\text { - } 15 \text { Temmuz Darbe Girişimi Olayı Sonrasında Gelişen Mantıksız Olumsuz } \\
\text { Düşünceleri Zihinsel Yeniden Yapılandırma } \\
\text { - } \quad \text { Yaşam Alanını (Bireysel-Ailesel) Düzenleme ve İlişkileri Yapılandırma } \\
\quad \text { Bireya Çıkma Kaynakları Kazandırma }\end{array}$ \\
\hline 8.Oturum & $\begin{array}{l}\text { - } \quad \text { Grup sürecinde öğrenilenleri gözden geçirme } \\
\text { - Gelecekte Olacak Sorunlar Hakkında Bireyi Dayanıklı Olmaya Hazır Kılma }\end{array}$ \\
\hline
\end{tabular}

\section{“Psikolojik Dayanıklılık Programı” Uygulanması}

Bu program 15 Temmuz Darbe Girişimi olayında eşi gazi olan kadınlara İstanbul İl Merkezi Fatih ve Beykoz İlçesi’nde İstanbul Büyükșehir Belediyesinin kültür merkezi toplantı salonunda dört uzman psikologla (iki uzman-iki yardımcı uzman) uygulanmıştır. Üyeler bir daire oluşturacak şekilde oturmuşlardır. Sekiz oturumluk eğitim programı sekiz hafta boyunca haftada bir gün şeklinde yürütülmüştür. Oturum süresi 90 dakika olarak uygulanmıştır.

\section{Verilerin Analizi}

Verilerin analiz edilmesi sürecinde, hangi testlerin kullanılacağına karar verebilmek amaciyla öncelikle her iki deney grubunda bulunan bireylerin PTSB-SLSV ve KTGÖ ön-test uygulamalarından elde ettikleri değerlerin; parametrik testlerin temel varsayımlarını karşılayıp karşılayamadıkları incelenmiştir. Yapılan işlemler verilerin homojen ve normal dağılıma sahip olduklarını göstermiştir. Deney gruplarında bulunan bireylerin; PTSB-SLSV ve KTGÖ ön-test ölçümlerine yönelik yapılan homojenlik ve normallik testlerinden elde edilen tüm sonuçlar birlikte ele alınarak araştırmada parametrik testlerin kullanılabileceğine karar verilmiştir.

Araştırmada, iki deney grubu bulunmaktadır. Deney gruplarında ölçümler açısından grupların kendi içinde ve bireyler içi ölçümleri söz konusudur. Ön-test, son-test ve izleme ölçümleri 
değişiminin, istatistiksel anlamlılığını kararlaştırmada kullanılan yollardan biri Tekrarlı Ölçümler İçin Tek Yönlü ANOVA'dır (Balcı, 1997). Bu analiz sonucunda anlamlı farkın gözlendiği durumlarda ise farkın kaynağını test edebilmek için veriler Tukey (HSD) testi ile analiz edilmiştir. Verilerin analizi için SPSS 23.0 paket programı kullanılmıştır.

\section{Bulgular}

Bu bölümde araştırmanın denencelerini test etmek üzere yapılan istatistiksel analizlere ve bu analizlerden elde edilen bulgulara yer verilmiştir.

\section{Ön Analiz Sonuçları}

Verilerin analiz edilmesi sürecinde, ön analiz olarak deney I ve II gruplarında bulunan bireylerin PTSB-SLVS ve KTGÖ ön-test uygulamalarından elde ettikleri değerlerin; parametrik testlerin temel varsayımlarını karşılayıp karşılayamadıkları incelenmiştir. Parametrik testin sonucuna göre deney I ve deney II gruplarının [PTSB-SLSV $\left(F_{(1-13)}=.213, p>.05\right)$, KTGÖ $\left(F_{(1-13)}=.4 .98\right.$, $p>.05)]$ ön-test ölçümlerinden aldıkları puanların ortalamaları arasında anlamlı bir fark olmadığı gözlenmiştir. Ayrica deney I [PTSB-SLSV, (.246, p>.05), KTGÖ (.143, p>.05)] ve deney II gruplarının [PTSB-SLSV (.014 $p>.05)$, KTGÖ $(.530, p>.05)]$ Kolmogorov-Smirnov testinden elde edilen değerlerin önem derecesinin $(p) .05$ 'ten büyük olması dağılımın normal olduğu göstermiştir (Büyüköztürk, 2002). Deney I ve deney II gruplarının her iki ölçeğe ilişkin ön-test ölçümlerinden elde ettikleri puanların çarpıklık (skewness) ve basıklık (kurtosis) düzeylerinin de +1 ile -1 arasında yer alması dağılımın normal olduğunu gözler önüne sermiştir (Büyüköztürk, 2002).

\section{Tek Yönlü Varyans Analiz Sonuçları}

Deney Grubundaki Travma Düzeyine İlişkin Denenceye Ait Bulgular: Araştırmanın birinci denencesi; "Psikolojik Dayanıklılık Programı kadınların travma sonrası stres düzeylerini azaltmada anlamlı düzeyde etkili olacaktır ve bu etki programın tamamlanmasından iki buçuk ay sonra yapılacak ölçümlerde de devam edecektir" şeklinde ifade edilmiştir. Deney gruplarında yer alan katılımciların PTSB-SLSV ön-test, son-test ve izleme testi aritmetik ortalamaları ve standart sapmaları aşağıdaki Tablo 4'te verilmiştir.

Tablo 4: Deney Gruplarının (PTSB) Soru Listesi Sivil Versiyonu, Aritmetik Ortalama ve Standart Sapma Değerleri

\begin{tabular}{lllllll}
\hline \multicolumn{1}{c}{ Ölçümler } & \multicolumn{2}{c}{ Ön-test } & \multicolumn{2}{c}{ Son-test } & \multicolumn{2}{c}{ İzleme testi I } \\
Gruplar & $\bar{X}$ & $S s$ & $\bar{X}$ & $S s$ & $\bar{X}$ & $S s$ \\
\hline Deney I N=7 & 59.28 & 5.87 & 51.29 & 7.54 & 46.86 & 7.17 \\
\hline Deney II N=8 & 57.38 & 7.05 & 45.75 & 7.046 & 40.62 & 6.54 \\
\hline
\end{tabular}

Tablo 4 incelendiğinde deney I ve deney II gruplarının ön test, son-test ve izleme puanlarında farklılıklar olduğu görülmektedir. Deney I ve II gruplarını PTSB-SLSV'den elde ettikleri ölçüm puan ortalamalarının arasındaki farkın anlamlı olup olmadığı tek yönlü varyans analizi (ANOVA) ile test edilmiştir. Elde edilen bulgular Tablo 5'te ve Tablo 6'da sunulmuştur. 
Tablo 5: Deney I Grubunun PTSB Soru Listesi Sivil Versiyonu Puanlarına İlişkin Tek Faktörlü Varyans Analizi Sonuçları

\begin{tabular}{|c|c|c|c|c|c|c|}
\hline Kaynak & $\begin{array}{l}\text { Kareler } \\
\text { Toplamı }\end{array}$ & $S d$ & $\begin{array}{l}\text { Kareler } \\
\text { Ortalaması }\end{array}$ & $F$ & $p$ & $\begin{array}{l}\text { Eta } \\
\text { Kare }\end{array}$ \\
\hline Gruplar İçi & 663.334 & 6 & & & & \\
\hline Ölçüm (ön-son-izleme) & 529.810 & 2 & 396. 984 & 23.807 & .001 & .799 \\
\hline Hata & 133.524 & 12 & 16.675 & & & \\
\hline
\end{tabular}

Tablo 6: Deney II Grubunun PTSB Soru Listesi Sivil Versiyonu Puanlarına İlişskin Tek Faktörlü Varyans

\begin{tabular}{|c|c|c|c|c|c|c|}
\hline Kaynak & $\begin{array}{l}\text { Kareler } \\
\text { Toplamı }\end{array}$ & $S d$ & $\begin{array}{l}\text { Kareler } \\
\text { Ortalamas1 }\end{array}$ & $F$ & $p$ & $\begin{array}{l}\text { Eta } \\
\text { Kare }\end{array}$ \\
\hline Gruplar içi & 1461.333 & 7 & & & & \\
\hline Ölçüm (ön-son-izleme) & $\begin{array}{l}1152.333 \\
309000\end{array}$ & $\begin{array}{l}2 \\
14\end{array}$ & $\begin{array}{l}658.900 \\
25.241\end{array}$ & 26.105 & .000 & .789 \\
\hline
\end{tabular}

Tablo 5'te ve 6' da görüldüğü gibi PTSB-SLSV üzerinden yapılan varyans analizi sonucunda bireylerin ön-test, son-test ve izleme testi ölçümlerinden elde ettikleri puanların ortalamaları arasındaki farkın da anlamlı olduğu görülmüsşür $\left(F_{(2-12)}=23.80 p<.01\right),\left(F_{(2-14)}=23.10 p<.01\right) . \mathrm{Bu}$ bulgu deney gruplarındaki bireylerin ön-test, son-test ve izleme test ölçümlerinde PTSB-SLSV'den elde ettikleri puanların değiştiğini göstermektedir. Tüm bu bulgular dikkate alındığında, araştırmada travma sonrası stresle ilgili öne sürülen denenceler doğrulanmaktadır. Ölçümler arasında anlamlı bir farkın hangi ölçümden olduğunu belirlemek için Tukey Testi yapılmıştır. Elde edilen değerler Tablo 6'da ve Tablo 7'de verilmiștir.

Tablo 7: PTSB Soru Listesi Sivil Versiyonlarının Ölçümler Arası Farklarına İlişkin Deney I Grubunun Tukey Testi Sonuçları

\begin{tabular}{llll}
\hline & Ön-Test & Son-Test & İleme Testi \\
\hline Ön-Test & - & $8^{*}$ & $12.429^{*}$ \\
Son-Test & & - & 4.429 \\
İzleme Testi & & & - \\
\hline $.05 * * p<.01$ & & &
\end{tabular}

Tablo 8: PTSB Soru Listesi Sivil Versiyonlarının Ölçümler Arası Farklarına İlişkin Deney II Grubunun Tukey Testi Sonucları

\begin{tabular}{llll}
\hline & Ön-Test & Son-Test & İzleme Testi \\
\hline Ön-Test & - & $11.625^{*}$ & $16.75^{*}$ \\
Son-Test & & - & 5.125 \\
İzleme Testi & & & - \\
${ }^{*} p<.05 * * p<.01$ & & &
\end{tabular}

Tablo 7 ve 8 incelendiğinde, araştırmanın ilk denencesinin kabul edildiği görülmektedir. Deney I ve II gruplarının PTSB-SLSV ön-testlerinden elde ettikleri puanların ortalamaları ile sontest ve izleme testi ölçümlerinden elde edilen puanların ortalamaları arasında anlamlı fark vardır.

Deney Gruplarının Psikolojik Dayanıklılık Düzeyine İlişkin Denenceye Ait Bulgular: Araştırmanın üçüncü denencesi; "Travma Sorununda Psikolojik Dayanıklılık Programı kadınların psikolojik dayanıklılık düzeylerini artırmada anlamlı düzeyde etkili olacaktır ve bu etki programın tamamlanmasından iki buçuk ay sonra yapılacak ölçümlerde de devam edecektir" şeklinde ifade 
edilmiştir. Deney grubunda yer alan katılımcıların ön-test, son-test ve izleme testi aritmetik ortalamaları ve standart sapmaları aşağıdaki Tablo 9'da verilmiştir.

Tablo 9: Deney Gruplarının Kendini Toparlama Gücü Ölçeği Aritmetik Ortalama ve Standart Sapma Değerleri

\begin{tabular}{lllllll}
\hline \multicolumn{1}{c}{ Ölçümler } & Ön-test & \multicolumn{3}{c}{ Son-test } & \multicolumn{2}{c}{ İleme testi I } \\
Gruplar & $\bar{X}$ & Ss & $\bar{X}$ & Ss & $\bar{X}$ & Ss \\
\hline $\begin{array}{l}\text { Deney I } \\
\mathrm{N}=7\end{array}$ & 112.29 & 7.06 & 141.57 & 11.11 & 148.71 & 7.15 \\
\hline $\begin{array}{l}\text { Deney II } \\
\mathrm{N}=8\end{array}$ & 117.63 & 3.021 & 144.5 & 9.181 & 151.62 & 6.86 \\
\hline
\end{tabular}

Tablo 9 incelendiğinde deney I ve deney II gruplarının ön-test, son-test ve izleme puanlarında farklılıklar olduğu görülmektedir. Deney I ve II gruplarının KTGÖ'den elde ettikleri ölçüm puan ortalamalarının arasındaki farkın anlamlı olup olmadığı tek yönlü varyans analizi (ANOVA) ile test edilmiştir. Elde edilen bulgular Tablo 10'da ve Tablo 11'de sunulmuştur.

Tablo 10: Deney I Grubunun Kendini Toparlama Gücü Ölçeği Puanlarına İlişkin Tek Faktörlü

\begin{tabular}{|c|c|c|c|c|c|c|}
\hline Kaynak & $\begin{array}{l}\text { Kareler } \\
\text { Toplamı }\end{array}$ & $S d$ & $\begin{array}{l}\text { Kareler } \\
\text { Ortalaması }\end{array}$ & $F$ & $p$ & $\begin{array}{l}\text { Eta } \\
\text { Kare }\end{array}$ \\
\hline Gruplar İçi & 5595.334 & 6 & & & & \\
\hline $\begin{array}{c}\text { Ölçüm (ön-son-izleme) } \\
\text { Hata }\end{array}$ & $\begin{array}{r}5216.667 \\
378.667\end{array}$ & $\begin{array}{l}2 \\
12\end{array}$ & $\begin{array}{r}2907.455 \\
35.174\end{array}$ & 82.658 & .000 & .932 \\
\hline
\end{tabular}

Tablo 11: Deney II Grubunun Kendini Toparlama Gücü Ölçeği Puanlarına İlişkin Tek Faktörlü

\begin{tabular}{lcccccc}
\multicolumn{8}{c}{ Varyans Analizi Sonuçları } \\
\hline Kaynak & $\begin{array}{l}\text { Kareler } \\
\text { Toplamı }\end{array}$ & $S d$ & $\begin{array}{l}\text { Kareler } \\
\text { Ortalaması }\end{array}$ & $F$ & $p$ & $\begin{array}{l}\text { Eta } \\
\text { Kare }\end{array}$ \\
\hline Gruplar içi & 4688.166 & 7 & & & & \\
Ölçüm (ön-son-izleme) & 5144.083 & 2 & 2633.433 & 78.981 & .000 & .919 \\
$\quad$ Hata & 455.917 & 14 & 33.343 & & & \\
\hline
\end{tabular}

Tablo 10'da ve 11'de görüldüğü gibi KTGÖ üzerinden yapılan varyans analizi sonucunda bireylerin ön-test, son-test ve izleme testi ölçümlerinden elde ettikleri puanların ortalamaları arasındaki farkın da anlamlı olduğu görülmüştür $\left(F_{(2-12)}=82.658 p<.01\right),\left(F_{(2-14)}=78.981 p<.01\right) . \mathrm{Bu}$ bulgu deney gruplarındaki bireylerin ön-test, son-test ve izleme testi ölçümlerinde KTGÖ'den elde ettikleri puanların değiştiğini göstermektedir. Tüm bu bulgular dikkate alındığında araştırmada psikolojik dayanıklılıkla ilgili öne sürülen denencenin doğrulandığı söylenebilir. Ölçümler arasında anlamlı bir farkın hangi ölçümde olduğunu belirlemek için Tukey Testi yapılmıştır. Elde edilen değerler Tablo 12'de ve Tablo 13 'te verilmiştir.

Tablo 12: Kendini Toparlama Gücü Ölçeğinin Ölçümler Arası Farklarına ilişkin Deney I

Grubunun Tukey Testi Sonuçları

\begin{tabular}{llll}
\hline & Ön-Test & Son-Test & İzleme Testi \\
\hline Ön-Test & - & $-29.286^{* *}$ & $-36.429^{* *}$ \\
Son-Test & & - & -7.143 \\
İzleme Testi & & & - \\
& & &
\end{tabular}


Tablo 13: Kendini Toparlama Gücü Ölçeğinin Ölçümler Arası Farklarına ilişkin Deney II Grubunun Tukey Testi Sonuçları

\begin{tabular}{llll}
\hline & Ön-Test & Son-Test & İzleme Testi \\
\hline Ön-Test & - & $-26.875^{* *}$ & $-34^{* *}$ \\
Son-Test & & - & -7.125 \\
İzleme Testi & & & - \\
\hline$<.05 * * p<.01$ & & &
\end{tabular}

Tablo 12 ve 13 incelendiğinde araştırmanın ikinci denencesinin kabul edildiği görülmektedir. Deney I ve II gruplarının KTGÖ'nün ön-testinden elde ettikleri puanların ortalamaları ile son-test ve izleme testi ölçümlerinden elde edilen puanların ortalamaları arasında anlamlı fark vardır. Bu durumda PDP'nin, deney grubundaki kadınların psikolojik dayanıklılık düzeylerini arttırmada anlamlı düzeyde etkili olduğu söylenebilir.

\section{Tartışma ve Sonuç}

Araştırmanın ilk sonucu; PDP'nin deney grubunda yer alan kadınların/gazi eşlerinin travma sonrası stres düzeylerini azaltmada etkili olmuştur. PDP üç yaklaşımın (bağlanma kuramı, bilişsel davranışçı yaklaşım ve sistemik aile terapisi) ilkeleri dikkate alınarak hazırlanmıştır. Bu üç yaklaşıma dayalı olup travma sonrası stres sorunu yaşayan gazi yakını (eş-çocuk) bireylerin travma sonrası stres düzeylerini azaltmada etkili olduğunu gösteren ve bu araştırmanın bulgularını destekleyen çalışmalara literatürde rastlanmaktadır (Kozlowska ve Hanney, 2002; Riggs ve Riggs, 2011; Sherman vd., 2009).

Literatürde PDP'deki bağlanma kuramı öğelerinin etkililiğini desteklediği düşünülen birçok araştırmaya rastlanmıştır. Bu çalışmalarda (Erbes vd., 2008; Johnson, 2002) duygu odaklı ve ilişkiyi güvenli bir stabilizasyona getiren uygulamaların gazi yakınlarının travma sonrası stres düzeylerini anlamlı düzeyde azalttığını ifade etmesi bu çalışmanın travma sonrası stres bulguları ile paralellik göstermektedir.

PDP'deki bilişsel davranışçı öğelerin (sokratik sorgulama, mantıksız inançları ele alma, inançları yeniden yapılandırma) etkililiğini desteklediği düşünülen birçok araştırma da literatürde vardır. Bu araştırmalarda (Monson vd., 2004; Monson vd., 2009a; 2009b) gazilerle ve gazi yakınlarıyla 15 seansta bireysel veya grup müdahale programları ile travma sonrası stres sorunundan kaynaklanan mantıksız düşüncelerin ve içeriklerinin yeniden yapılandırılmasının katılımcıların hem ilişkilerini düzenlediğini hem de travma sonrası stres düzeylerini anlamlı düzeyde azalttığını ifade etmesi bu çalışmaların travma sonrası stres bulgularını destekleyebilir (Monson vd., 2011; Monson vd., 2009a; 2009b).

PDP'deki sistemik aile terapisi kuramının öğelerinin etkililiğini destekleyen birçok araştırmaya da literatürde rastlanmıştır. Bu çalışmalarda (Boss, 2007; Nelson-Goff ve Smith, 2005; Sayers, Farrow, Ross ve Oslin, 2009) gazi yakınları için hazırlanan 8-12 hafta süren grup müdahale programlarının [Çiftin Travma Sonrası Strese Uyum Modeli/CATS (Nelson-Goff ve Smith, 2005), Sağlıklı ve İlgilenen Aileleri Eğitme ve Yardım Etme Programı/REACH (Sherman vd., 2009)] katılımcıların travma sonrası stres düzeylerini anlamlı düzeyde azalttığını belirtmesi bu çalışmaların travma sonrası stres ile ilgili bulgularını destekler nitelikte olabilir.

Araştırmanın ikinci temel sonucu PDP deney grubunda yer alan kadınların/gazi eşlerinin psikolojik dayanıklılık düzeylerini artırmada etkili olmuştur. Bu araştırmada uygulanan PDP'de gazi eşinin ilişkilerindeki riskler (öfke, izolasyon) kaynaklar (sosyal, duygusal ve çevresel destek vb.) ve ilişkilerinin iletişimi üzerinde durulmuş ve katılımcıların psikolojik dayanıklılık düzeylerinin arttığı görülmüştür. Bu bulgu literatürdeki birçok çalışmanın (Charuvastra ve Cloitre, 2008; Kozlowska ve Hanney, 2002; Riggs ve Riggs, 2011) ve gazi yakınlarında yapılan etkiliği kanıtlanmış psikolojik 
dayanıklılıkla ilgili programların [Çiftler ve Aileler için Güçlü Bağlar (Stanley vd., 2005), REACH (Sherman vd., 2009)] bulguları ile paralellik göstermektedir.

Son olarak bu çalışmanın travma sonrası stres düzeylerini azaltan ve aile dayanıklılı̆̆ını arttıran etkililiği kanıtlanmış bir deneysel çalışma olmasında programın genel yapısında ve içeriğinde yer alan çeşitli özelliklerin de etkisi olabilir. Programın genel yapısı ve içeriğinin biyopsikososyal bakış açısı dikkate alınarak hazırlanması, programın merkezine ilişkinin yerleştirilmesi, programda bireylerin kendilerini/düşüncelerini/davranışlarını/duygularını sorgulaması, programda duyguların ve bedensel duyumların fark edilmesi ve paylaşılması, programda olumsuz yaşantıların kaynaklar bağlamında ele alınması, programda ev ödevlerinin olması, programın uzmanlar tarafından gözden geçirilmesi, programa katılan katılımcıların travma sonrası stres düzeylerini azaltmada ve psikolojik dayanıklılık düzeylerini anlamlı azaltmada etki etmiş olabilir.

$\mathrm{Bu}$ araştırmanın sonuçları göz önünde bulundurulduğunda araştırmanın çeşitli sınırlılıkları olduğu söylenebilir. Bu sınırlılıklar dikkate alındığında da araştırmacı ve uygulayıcılara şu önerilerde bulunulabilir. Bu çalışmanın bulguları 15 Temmuz Darbe Girişimi sonucu eşi gazi olan kadınlardan elde edilen sonuçlarla sinırlıdır. Ancak günümüzde dünyada giderek artan savaş ve terör mağduriyeti sonucunda birçok aile üyesi travma sonrası stresle karşılaşmaktadır. Bu anlamda bu çalışma savaştan ve terörden dolayı travma sonrası stres bozukluğu yaşayan bireyler üzerinde de uygulanıp test edilebilir. Bu çalışmada deney grubuna ivedilikle müdahale edilmesi gerektiği için kontrol grubu bulunmamaktadır. İleriki çalışmalarda kontrol grubuyla bu çalışma test edilip araştırmanın etkililiği güçlendirilebilir. Ayrıca bu çalışma yetişkin kadınlardan elde edilen sonuçlarla sınırlıdır. Kadınlar kadar gazi bireyin yaşadığı sorunlardan ailedeki çocuklar da çok etkilenmektedir. Bu yüzden benzer bir çalışma çocuk ve ergen grupları üzerinde de denenebilir. Bu çalışmanın en büyük sınırlılığı kontrol grubunun olmayışıdır. Bu yüzden programın etkililiğini istatisksel olarak daha etkin kılmak adına ileride yapılacak çalışmalarda kontrol grubunun kullanılması önerilmektedir. Psikolojik dayanıklılık kavramı çok boyutlu bir kavram olduğundan bu kavramı ölçen güvenilir ve geçerli az sayıda ölçme aracı literatürde bulunmaktadır. Bu çalışmada psikolojik dayanıklılığı gazi yakınlarının yaşadıkları travma sonrası stres özelliklerine göre ölçmek için Kendini Toparlama Gücü Ölçeği kullanılmıştır. Kısacası bu çalışmanın verileri farklı bir grupta geliştirilmiş bir ölçekten elde edilen sonuçlarla sınırlıdır. Bu yüzden, psikolojik dayanıklılık alt boyutlarının sadece gazi yakınlarında travma sorunu dikkate alınarak oluşturulduğu ve travma sonrası stres grubuna uygulandığı bir psikolojik dayanıklılık ölçeği geliştirilebilir. Bu bağlamda geliştirilen psikolojik dayanıklılık ölçeğiyle benzer bir çalışma tekrar uygulanıp etkililiği tespit edilebilir.

Son olarak bu araştırma PDP'nin etkililiği iki buçuk aylık izleme testi sonucuyla sınırlıdır. PDP'nin 1-2 yıl gibi daha uzun süreli etkililiğine bakılabilir ve kalıcılığg test edilebilir. Son olarak bu araştırmada geliştirilen PDP, psikolojik danışma ve rehberlik ve psikoloji alanında çalışan uzmanlar tarafından kolaylıkla kullanılabilecek biçimde organize edilmiştir. Bu bağlamda uzmanlar tarafindan tekrar uygulanıp test edilebilir.

\section{Kaynakça}

Ahmadi, K., Azampoor-Afshar, S., Karami, G. ve Mokhtari, A. (2011). The association of veteran's PTSD with secondary trauma stress among veterans' spouses. Journal of Adjustment, Maltreatment, \& Trauma, 20, 636-644.

Balc1, A. (1997). Sosyal Bilimlerde Araştırma: Yöntem, Teknik ve İlkeler, Ankara: TDFO Yayınları.

Boss, P. (2007). Ambiguous loss theory: Challenges for scholars and practitioners. Family Relations, 56, 105-111. 
Boss, P. ve Couden, B. (2002). Ambiguous loss from chronic physical illness. Journal of Clinical Psychology, 58(11), 1351-1360.

Bride, B.E. ve Figley, C.R. (2009). Secondary trauma and military veteran caregivers. Smith College Studies in Social Work, 79(3-4), 314-329.

Büyüköztürk, Ş. (2002). Deneysel Desenler Öntest-Sontest Kontrol Gruplu Desen ve Veri Analizi. Ankara: Pegem A Yayıncilık

Calhoun, P.S., Beckham, J.C. ve Bosworth, H.B. (2002). Caregiver burden and psychological distress in partners of veterans with chronic posttraumatic stress disorder. Journal of Stress, 15, 205212.

Charuvastra, A. ve Cloitre. M. (2008). Social bonds and posttraumaticstress disorder. Annual Review of Psychology, 59, 301-328.

Chandra, A., Sandraluz, L.C., Jaycox, L.H., Tanielian, T., Burns, R., Ruder, T. vd. (2010). Children on the homefront: The experience of children from military families. Pediatrics, 125(1),1625.

Dekel, R. ve Goldblatt, H. (2008). Is there intergenerational transmission of trauma? The case of combat veterans'children. American Journal of Orthopsychiatry, 78(3),281-289.

Dekel, R., Goldblatt, H., Keidar, M., Solomon, Z. ve Polliack, M. (2005). Being a Wife of a Veteran with Posttraumatic Stress Disorder. Family Relations, 54, 24-36.

Dekel, R., Solomon, Z. ve Bleich, A. (2005). Emotional distress and marital adjustment of caregivers: Contribution of level of impairment and appraised burden. Anxiety, Stress, and Coping: An International Journal, 18, 71-82.

Dekel, R. ve Solomon, Z. (2006). Marital relations among former prisoners of war: contribution of posttraumatic stress disorder, aggression, and sexual satisfaction. Journal of Family Psychology, 20(4), 709-712.

Dirkzwager, A.J.E., Bramsen, I., Adèr, H. ve van der Ploeg, H.M. (2005). Secondary traumatization in partners of Dutch peacekeeping soldiers. Journal of Family Psychology, 19, 217-226.

Duran, S. ve Ünsal, G. (2014). Çankırı ilindeki şehit aileleri ve malul gazilerin psikolojik dayanıklılık ve depresif durumlarının belirlenmesi. Acıbadem Üniversitesi Sağllk Bilimleri Dergisi, 5(2), 158- 163 .

Erbes, C. R., Polusny, M. A., MacDermid, S. M., ve Compton, J. S. (2008). Couple therapy with combat veterans and their partners. Journal of Clinical Psychology, 64, 972-983.

Francisković, T., Stevanović, A., Jelusić, I., Roganović, B., Klarić, M., ve Grković, J. (2007). Secondary traumatization of wives of war veterans with posttraumatic stress disorder. Croatian Medicine Journal, 48, 177-184.

Galovskia, T. ve Lynosa, J.A. (2004). Psychological sequelae of combat violence: A review of the impact of PTSD on the veteran's family and possible interventions. Aggression and Violent Behavior, 9, $477-501$.

Gates, M.A., Holowka, D.W., Vasterling, J.J., Keane, T.M., Marx, B.P. ve Rosen, R.C. (2012). Posttraumatic stress disorder in veterans and military personnel: Epidemiology, screening, and case recognition. Psychological Services, 9(4), 361-382.

Gewirtz, A.H., Polusny, M.A., DeGarmo, D.S., Khaylis, A. ve Erbes, C.R. (2010). Posttraumatic stress symptoms among National Guard soldiers deployed to Iraq: Associations with

www.turkishstudies.net/social 
parenting behaviors and couple adjustment. Journal of Consulting and Clinical Psychology, 78,599610 .

Gilbert, K. (2000). Understanding the secondary traumatic stress of spouses. In: Figley, C. R, editor. Burnout in families: The Systematic costs of caring. New York (NY): CRC Press. p. 47-75.

Güloğlu, B. ve Irmak, O. (2013). Güneydoğu gazilerinde travma sonrası stres bozukluğu gelişimi. Anadolu Psikiyatri Dergisi, 14, 237-44.

Johnson, S.M. (2002). Emotionally focused couple therapy with trauma survivors: Strengthening attachment bonds. NY: Guilford.

Koszlowska, K., ve Hanney, L. (2002). The network perspective: An integration of attachment and family systems theories. Family Process, 41, 285-312.

Kessler, R.C. (2000). Posttraumatic stress disorder: the burden to the individual and to society. Journal of Clinical Psychiatry, 61(5), 4-12.

Kessler, R.C, Rose, S., Koenen, K.C., Karam, E.G., Stang, P.E., Stein, D.J. vd. (2014). How well can post-traumatic stress disorder be predicted from pre-trauma risk factors? an exploratory study in the WHO World Mental Health Surveys. World Psychiatry, 13(3), 265-274.

Manguno-Mire, G., Sautter, F., Lyons, J.A., Myers, L., Perry, D., Sherman, M. vd. (2007). Psychological distress and burden among female partners of combat veterans with PTSD. Journal of Nervous \& Mental Disease, 195, 144-151.

Mansfield, A.J., Kaufman, J.S., Marshall, S.W., Gaynes, B.N., Morrissey, J.P., Engel, C.C. (2010). Deployment and the use of mental health services among U.S. Army wives. New England. Journal of Medicine, 362, 101-109.

Monson, C.M., Fredman, S.J., Adair, K.C., Stevens, S.P., Resick, P.A., Schnurr, P.P., MacDonald, H.Z. ve Macdonald, A. (2011). Cognitive-Behavioral Conjoint Therapy for PTSD: Pilot Results From a Community Sample. Journal of Traumatic Stress, 24(1) 97-101.

Monson, C.M., Fredman, S.J., Macdonald, A., Pukay-Martin, N., Resick, P.A., \& Schnurr, P.P. (2012). Effect of cognitive-behavioral couple therapy for PTSD; A randomized controlled trial. Journal of the American Medical Association, 308(7), 700-709.

Monson, C.M., Gradus, J.L., La Bash, H.A.J., Griffin, M.G. ve Resick, P.A. (2009a). The role of couples' interacting world assumptions and relationship adjustment in women's post-disaster PTSD symptoms. Journal of Traumatic Stress, 22, 276-281.

Monson, C.M., Price, J.L., Rodriguez, B.F., Ripley, M.P. ve Warner, R. (2004a). Emotional deficits in military-related PTSD: An investigation of content and process disturbances. Journal of Traumatic Stress, 17, 275-279.

Monson, C.M., Schnurr, P.P., Stevens, S.P. ve Guthrie, K.A. (2004b). Cognitive-behavioral couple' treatment for posttraumatic stress disorder: Initial findings. Journal of Traumatic Stress, 17, 341-344.

Monson, C.M., Taft, C.T. ve Fredman, S.J. (2009b). Military-related PTSD and intimate relationships: From description to theory-driven research and intervention development. Clinical Psychology Review, 29, 707-714.

Nelson-Goff, B.S. ve Smith, D.B. (2005). Systemic traumatic stress: the couple adaptation to traumatic stress model. Journal of Marital and Family Therapy, 31(2), 145-157. 
Richardson, L.K., Frueh, B.C., ve Acierno, R. (2010). Prevalence estimates of combat-related posttraumatic stress disorder: Critical review. Australian and New Zealand Journal of Psychiatry, 44, 4-19.

Riggs, D.S., Monson, C.M., Glynn, S., \& Canterino, J. (2009). Couples and family therapy. In E. B. Foa, T. M. Keane, M. J. Friedman, \& J. A. Cohen (Eds.), Effective treatments for PTSD: Practice guidelines from the International Society for Traumatic Stress Studies (2nd ed., pp. 458-478). New York, NY: Guilford Press.

Riggs, S.A. ve Riggs, D.S. (2011). Risk and resilience in military families experiencing deployment: the role of the family attachment network. Journal of Family Psychology, 25(5), 675-687.

Sayers, S.L., Farrow, V., Ross, J. ve Oslin, D.W. (2009). Family problems among recentl returned military veterans. Journal of Clinical Psychiatry, 70, 163-170.

Sherman, M.D., Fischer, E.P., Sorocco, K. ve McFarlane, W.R. (2009). Adapting the multifamily group model to the veterans affairs system: The REACH program. Professional Psychology: Research and Practice, 40(6), 593-60.

Sundin, J., Fear, N.T., Iversen, A., Rona, R.J., ve Wessely, S. (2010). PTSD after deployment to Iraq: Conflicting rates, conflicting claims. Psychological Medicine, 40, 367-382.

Stanley, S.M., Allen, E.S., Markman, H.J., Saiz, C.C., Bloomstrom, G., Thomas, R. vd. (2005). Dissemination and evaluation of marriage education in the Army. Family Process, 44, 187-201.

Yambo, T.W., Johnson, M.E., Delaney, K.R., Hamilton, R., Miller, A.M., \& York, J.A. (2016). Experiences of military spouses of veterans with combat-related posttraumatic stress disorder. Journal of Nursing Scholarship, 48(6), 543-55.

Weathers, F.W., Litz, B.T., Herman, D.S., Huska, J.A. ve Keane, T.M. (1993). The The PTSD Checklist (PCL): Reliability, validity, and diagnostic utility. Paper presented at the 9th Annual Conference of the ISTSS, San Antonio, TX

Walsh, F. (2003). Family Resilience: A Framework for Clinical Practice. Family Process, 42(1), 118.

Walsh, F. (2006). Strengthening Family Resilience (2nd ed). New York: The Guilford Press.

15 Temmuz Derneği (2020). 15 Temmuz Derneği Hakkımızda: Erişim adresi: http://www.15temmuzdernegi.org/hakkimizda/ 


\section{KURUM DİLEKÇESİ}

7.02 .2020

Ilgili Makama,

15 Temmuz Darbe Girișimi olayım akabinde Ruh Sağhğı alanında Çalışan Uzman Kadın Derneḡi (RUHSAK) ile 15 Temmuz Darbe Girișimi olayından sontra etkilenen bireyleri desteklemek amacıyla kurulan 15 Temmuz Derneḡj işbirliggi yapmış ve RUHSAK yönetim kurulu đyesi olan Dr. Neslihan Ancı Özcan tarafindan 15 Temmuz Darbe Girişimi olayı sonrasında eşi gazi olan 15 kadına Ekim 2016- Haziran 2017 arasunda Psikolojik Dayanıklılık Programı altunda uzman eşliģ̧inde desteklenmiștir. Uygulanan programdan elde edilen sonuçlar bilimsel olarak yayına döndürülmesi içinde hem 15 Temmuz Derneği yetkililerinden hem de katılımcılardan onam ahıarak izin alınmıștır.

15 Temmuz Demeği

Yơnetim Kurulu Başkanı Tarik ȘEBIK
Istanbul Medeniyet Üniversitesi

Öretim Dyesi

Neslihan ARICI OZCAN 